\title{
Intraretinal worm documented by optical coherence tomography in a patient with diffuse unilateral subacute neuroretinitis: case report
}

\author{
Larva intrarretiniana documentada pela tomografia de coerência óptica em um paciente com \\ neurorretinite subaguda difusa unilateral: relato de caso
}

\author{
Leonardo Provetti Cunha ${ }^{1}$, Luciana Virgínia Ferreira Costa-Cunha ${ }^{1}$, Eduardo Cunha de Souza ${ }^{2}$, Mário Luiz R. Monteiro ${ }^{1}$
}

\begin{abstract}
Our purpose is to report a case of diffuse unilateral subacute neuroretinitis (DUSN) in which an ophthalmoscopically visible worm was found and optical coherence tomography $(\mathrm{OCT})$ scans allowed the precise localization of the parasite in the intraretinal layers. Our findings suggest that the parasite moves in the inner portions of the retina possibly explaining the severe degenerative neural changes that it causes.
\end{abstract}

Keywords: Retinitis/parasitology; Optic neuritis/pathology; Eye infections, parasitic; Tomography, optical coherence; Visual acuity; Nerve fibers/pathology; Human; Male; Adult; Case report

\section{RESUMO}

Nosso objetivo é relatar um caso de neurorretinite subaguda unilateral difusa (DUSN), onde uma larva oftalmoscopicamente visível foi detectada e, através do escaneamento pela tomografia de coerência óptica (OCT), foi possível estabelecer a localização precisa do parasita entre as camadas da retina. Nossos resultados sugerem que o movimento do parasita nas camadas mais internas da retina possa explicar as graves alterações neuronais degenerativas encontradas.

Descritores: Retinite/parasitologia; Neuriteóptica; Infecçõesoculares parasitárias; Tomografia de coerência óptica; Acuidade visual; Fibras nervosas; Humanos: Masculino; Adulto; Relatos de casos

\section{INTRODUCTION}

D fuse unilateral subacute neuroretinitis (DUSN) is a clinical syndrome characterized initially by visual loss, vitreitis, papillitis, retinal vasculitis and recurrent crops of evanescent grey-white outer retinal lesions and later, by progressive visual loss, optic atrophy, retinal vessel narrowing and diffuse retinal epithelium pigment degeneration occurring in one eye of otherwise healthy patients ${ }^{(1-2)}$. DUSN is caused by a single nematode that may wander in the retina but the exact location of the worn has not been definitively proven. We report a case of DUSN in which an ophthalmoscopically visible worm was found and optical coherence tomography (OCT) scans allowed the precise localization of the parasite in the intraretinal layers.

\section{CASE REPORT}

A 24-year-old man presented with an 11-month history of decreasing vision on his left eye (OS). On examination visual acuity was 20/20 in right eye (OD) and hand motion (HM) in OS. Pupils were equal in size and there was a severe relative afferent

Work carried out at the Department of Ophthalmology, São Paulo University - USP.

Physician, Division of Ophthalmology, Hospital das Clínicas, Faculdade de Medicina, Universidade de São Paulo - USP - São Paulo (SP), Brazil.

Physician, Ophthalmology Department, Universidade Federal de São Paulo - UNIFESP - São Paulo (SP), Brazil.

Correspondence address: Leonardo Provetti Cunha. Av. Rio Branco 4.051 - Juiz de Fora (MG) - CEP 36021-630 - E-mail: leonardo provetti@yahoo.com.br

Recebido para publicação em 14.09.2009

Ultima versão recebida em 16.11.2009

Aprovação em 25.12.2009

Nota Editorial: Depois de concluída a análise do artigo sob sigilo editorial e com a anuência dos Drs. André Romano e Rosane da Cruz Ferreira sobre a divulgação de seus nomes como revisores, agradecemos suas participaçöes neste processo. papillary defect in OS. Slit lamp examination and intraocular pressure measurements were unremarkable. Fundus examination was normal in OD and revealed marked optic atrophy, diffuse retinal vessels narrowing and diffuse pigmentation in the retina (Figure 1A). A non-mobile circle worn was observed in the infra nasal peripapillary area (Figure 1B). Using external fixation and with the line scan protocol of Stratus-OCT passing through the worm location, we were able to document two hyper reflective points in intraretinal space above the pigment ephithelium-choriocapillary complex (Figure 2). The retinal nerve fiber layer and macula thickness were severely reduced (Figure 2). Laser photocoagulation of the worm was performed but visual improvement was not achieved.

\section{DISCUSSION}

DUSN is a challenging ocular disease with many unanswered questions regarding its etiopathogeny. Some authors ${ }^{(3)}$ in a histopathological analysis of a patient with DUSN demonstrated an extensive retinal degeneration, gliosis, inflammatory cell infiltration and pigment-laden macrophages affecting all retinal layers, with partial loss of the ganglion cell layer and receptor elements. These changes are in agreement with our findings. In our case, OCT showed that both retinal nerve fiber layer (RNFL) and macular thickness measurements were severely reduced, suggesting that changes in later stages of disease were secondary to diffuse inflammatory or toxic process involving both the inner and outer retinal layers as well the optic nerve. The reduction of RNFL thickness measurements in patients with DUSN was previously demonstrated in others studies ${ }^{(4-5)}$.

Many authors have tried to establish the exact location of the nematode in the ocular fundus using non invasive methods but have been unsuccessful(6-7). Other authors ${ }^{(8)}$ surgically extracted a nematode through a retinotomy after pars plana vi- 

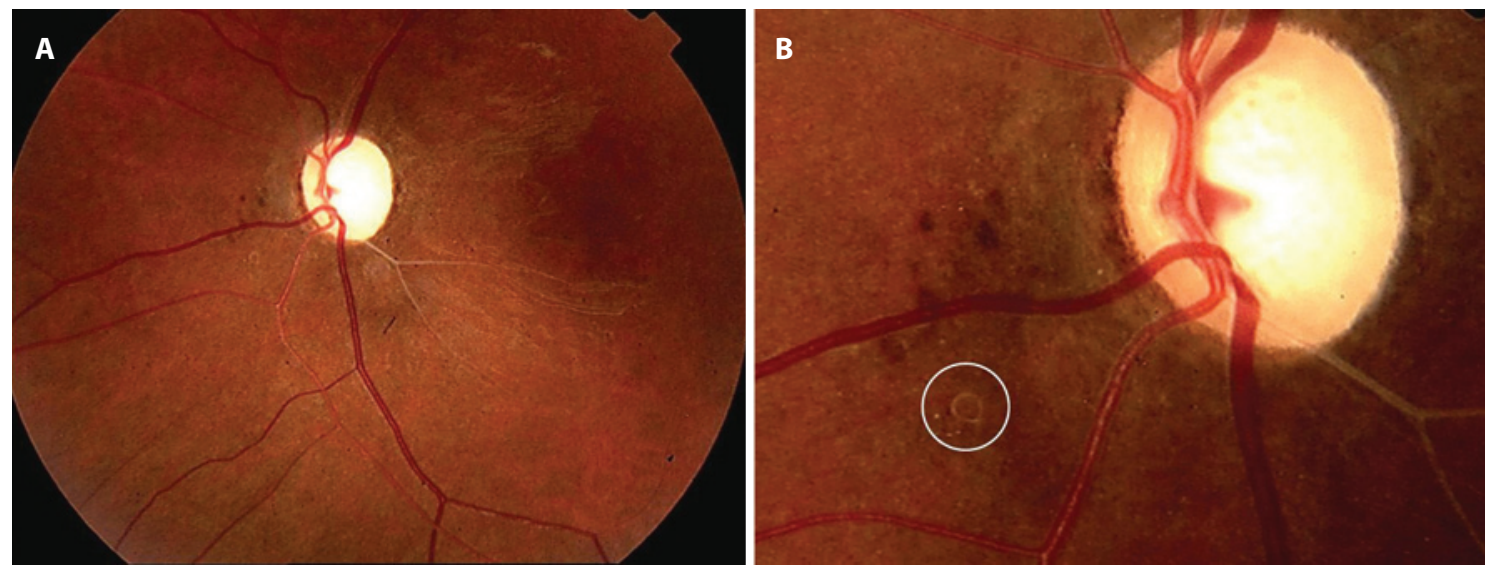

Figure 1. A) Fundus examination showing marked optic atrophy, diffuse retinal vessels narrowing and diffuse pigmentation in the retina. B) Note a non-mobile circle worn in the infra nasal peripapillary area (white circle).
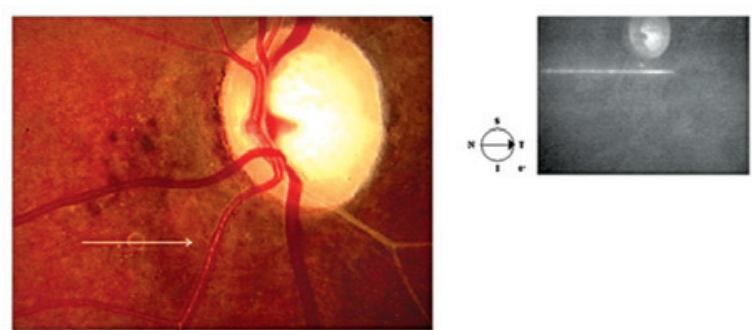

RNFL thickness
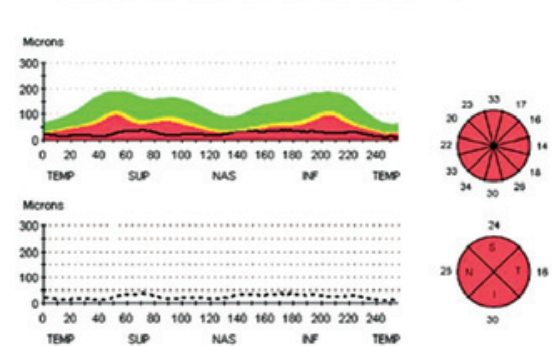

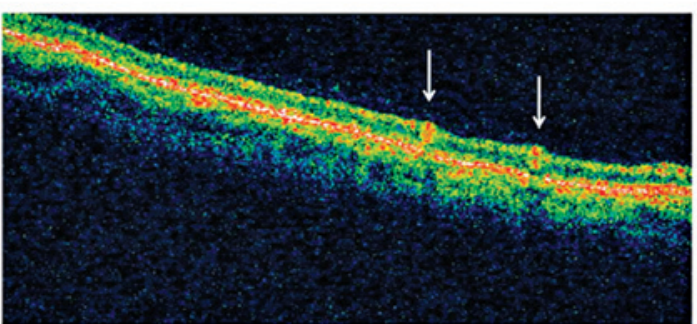

Macular thickness

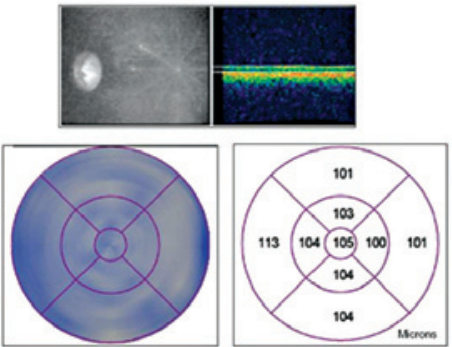

Figure 2. Above: The line scan protocol of Stratus-OCT passing through the worm location (horizontal white arrow), documenting two hyper reflective points in intraretinal space above the pigment ephithelium-choriocapillary complex (vertical white arrows). Below: OCT showing that retinal nerve fiber layers and macular thickness measurements was severely reduced.

trectomy in a case of DUSN and suggested that the worn was presumably located in the sub-retinal space. However, questions remain regarding on which layer of the retina mobile larva was located and no previous addressed this issue.

Our case is interesting because we were able to demonstrate for the first time the exact location in the retina of the worm using Stratus-OCT. Our findings suggest that the parasite moves in the inner portions of the retina possibly explaining the severe degenerative neural changes that it causes. Whether the parasite moves always in the inner retina or travels freely in different areas of the posterior pole, however, remains unclear.

\section{REFERENCES}

1. Gass JD, Gilbert WR Jr, Guerry RK, Scelfo R. Diffuse unilateral subacute neuroretinitis. Ophthalmology. 1978;85(5):521-45.

2. Souza EC, Casella AM, Nakashima Y, Monteiro ML. Clinical features and outcomes of patients with diffuse unilateral subacute neuroretinitis treated with oral alben- dazole. Am J Ophthalmol. 2005;140(3):437-45. Erratum in: Am J Ophthalmol. 2006; 141(4):795-6.

3. Gass JD, Scelfo R. Diffuse unilateral subacute neuroretinitis. J R Soc Med. 1978; 71(2):95-111.

4. Garcia CA, de Oliveira AG, de Lima CE, Rocha GN, Garcia Filho CA. Retinal nerve fiber layer analysis using GDx in 49 patients with chronic phase DUSN. Arq Bras Oftalmol. 2006;69(5):631-5.

5. Gomes AH, Garcia CA, Segundo Pde S, Garcia Filho CA, Garcia AC. Optic coherence tomography in a patient with diffuse unilateral subacute neuroretinitis. Arq Bras Oftalmol. 2009;72(2):185-8.

6. Moraes LR, Cialdini AP, Avila MP, Elsner AE. Identifying live nematodes in diffuse unilateral subacute neuroretinitis by using the scanning laser ophthalmoscope. Arch Ophthalmol. 2002;120(2):135-8.

7. Vianna RN, Onofre G, Ecard V, Muralha A, de Garcia CA. Indocyanine green angiography in diffuse unilateral subacute neuroretinitis. Eye (Lond). 2006;20(9): 1113-6.

8. de Souza EC, Nakashima Y. Diffuse unilateral subacute neuroretinitis. Report of transvitreal surgical removal of a subretinal nematode. Ophthalmology. 1995; 102(8):1183-6. 